\title{
PERKEMBANGAN MUSEUM KARO LINGGA DI DESA LINGGA KABUPATEN KARO
}

\author{
Oleh: \\ Ika Purnama Sari \\ Unjuk Kita Remenda
}

\begin{abstract}
ABSTRAK
Penelitian ini bertujuan untuk mengetahui "Perkembangan Museum Karo Lingga di Desa Lingga Kabupaten Karo". Adapun tujuan penelitian ini ialah untuk mengetahui latar belakang sejarah berdirinya Yayasan Museum Karo Lingga, untuk mengetahui koleksi Museum Karo Lingga, untuk Mengetahui bagaimana usaha pengelola Museum dalam melestarikan Koleksi Museum Karo Lingga, dan untuk mengetahui aktivitas masyarakat di desa Lingga. Untuk mencapai tujuan penelitian, maka penulis menggunakan metode penelitian deskriptif kualitatif dengan menggunakan teknik pengumpulan data berupa wawancara, observasi, dan dokumentasi. Dari hasil penelitian ini maka didapatkan data mengenai pembangunan museum, bangunan di disiberikan kepada Bapak G.H. Mantik pada tahun 1979 dan disahkan sebagai museun pada tahun 1989. Bangunan Museum Karo Lingga secara keseluruhannya menggambarkan bangunan yang memadukan gaya arsitektur rumah adat tradisional Karo. Semua koleksi yang ada di museum ini merupakan peninggalan yang berhubungan dengan kehidupan masyarakat Karo, sebagai bentuk melestarikan budaya Karo agar dapat mengingatkan masyarakat tentang kebudayaan asli suku Karo sebagai jejak peninggalan nenek moyang mereka.
\end{abstract}

Kata kunci: Museum Karo, Lingga 


\section{PENDAhuluan}

Warisan pra kolonial di Tanah Karo sampai sekarang masih dapat dilihat jejak keberadaannya, salah satunya adalah Rumah Tradisional Kalak Karo atau disebut dengan Siwaluh Jabu. Kompleks perumahan tradisonal yang dahulunya merupakan sebuah kota tersendiri bagi masyarakat Karo dataran tinggi, sebagian kecil dari kompleks perumahan tradisonal yang terselamatkan dari kejadian revolusi sosial tahun 1946.

Saat ini Desa Lingga terkenal sebagai salah satu desa yang masih mempertahankan kawasan kompleks perumahan tradisional Kalak Karo. Menurut cerita-cerita orang tua, ratusan tahun lalu Desa Lingga Kecamatan Simpang Empat merupakan cikal bakal serta pusat pemerintahan suku Karo. Saat itu Desa Lingga dipimpin seorang raja yang disebut Sibayak Lingga. Ia membangun rumah pertemuan dan rumah tempat tinggal warganya dengan tiang penyangga, dinding dan beberapa bagian atas terbuat dari kayu bulat.

Ketika Belanda menjajah negeri ini, warga Karo sengaja membumi-hanguskan rumah dan hartanya, agar rumah mereka tidak dimanfaatkan Belanda. Maka, pada saat ini hanya Desa Lingga, Peceren, Serdang, Barusjahe, dan Dokan yang mempunyai rumah adat pertanda kebesaran nenek moyang suku Karo.

Situs yang diinventarisasi pada kesempatan ini berupa peninggalan bangunan tradisional di perkampungan tradisional, bangunan tradisional di wilayah yang pada awal pendirian kampung tersebut sebagai perkampungan tradisional, makam dan bangunan tradisional Karo yang diperuntuhkan untuk Museum dengan sejumlah koleksi.

Di Kabupaten Karo, Provinsi Sumatera Utara terdapat sebuah museum daerah yang terletak di desa Lingga, kecamatan Simpang Empat. Desa Lingga merupakan salah satu desa yang menjadi daerah tujuan wisata di Kabupaten Karo. Bukan hanya keberadaan museum, disana juga terdapat rumah-rumah adat yang diperkirakan berumur 250 tahun, dan kondisinya masih kokoh. 
Museum Karo Lingga yang terletak $5 \mathrm{~km}$ di sebelah barat Kabanjahe sekitar 1 km sebelum lokasi Perkampungan tradisional Lingga, yang didirikan pada tahun 1977 atas prakarsa G.H. Mantik, Pangkowilham Kodam II Bukit Barisan pada waktu itu dan resmi dibuka pada tanggal 6 Juni 1989. Museum ini dikelola oleh Yayasan Museum Karo Lingga. (Mardiana 2009 : 37).

Alasan G.H. Mantik membangun rumah ini ketika dia berjalan di desa Lingga dia beberapa kali terjatuh di lokasi rumahnya dibangun tersebut. Dia merenung dan menganggap tanah tersebut baik dan dia berinisiatif untuk membangun rumah ditempat dia jatuh tersebut. Kemudian dia meminta bantuan kepada bapak Acie ginting untuk membangun rumah yang sekarang menjadi Museum Karo Lingga. Setelah rumah tersebut selesai dibangun maka diadakan mengket rumah sesuai dengan adat Karo. Let. Jend. TNI. G.H. Mantik diberi marga Manik dan istrinya juga di beri marga yaitu br Sinulingga.

Let. Jend. TNI. G.H. Mantik, seorang pejabat di Kodam II Bukit Barisanini membangun rumahnya tersebut pada tahun 1977. Pada tahun 1986 ada seorang penjaga Museum Negeri Medan mengusulkan agar rumah tersebut dijadikan sebagai museum lalu G.H. Mantik berinisiatif membuka Museum Karo di desa Lingga tersebut. Yayasan Museum Karo Lingga resmi dibuka pada tanggal 6 juni 1989. Selanjutnya Museum ini dipercayakan untuk dikelola oleh Acie Ginting secara swadana.

Koleksi museum menggambarkan berbagai perlengkapan hidup yang dulu sering dipakai orang Karo dalam kehidupan sehari-hari. Museum Karo Lingga ini terkesan ala kadarnya.Perkembangan zaman mendorong terjadinya perubahanperubahan dalam segala bidang, termasuk kebudayaan. Sempat ada pemikiran bahwa Museum Karo Lingga dibangun dari sisa runtuhan Museum Raya, tetapi hal tersebut tidak benar karena benda-benda peninggalan yang ada di Museum Karo Lingga merupakan benda-benda yang disumbangkan dan dibeli dari masyarakat yang ada di sekitar wilayah desa Lingga tersebut.

Berdasarkan kenyataan yang telah diuraikan di atas, maka penulis tertarik untuk meneliti mengenai "Perkembangan Museum Karo Lingga di Desa Lingga Kabupaten 
Karo”. Adapaun hal yang ingin diteliti ialah sebagai berikut: untuk mengetahui latar belakang berdirinya Museum Karo Lingga di Kabupaten Karo, untuk mengetahui koleksi Museum Karo Lingga, untuk mengetahui bagaimana usaha pengelola Museum dalam melestarikan koleksi Museum Lingga, dan untuk mengetahui aktivitas masyarakat di sekitar Museum Karo Lingga.

Untuk memudahkan peneliti dalam memperoleh data yang dibutuhkan, Untuk mencapai tujuan penelitian, maka penulis menggunakan metode penelitian deskriptif kualitatif dengan menggunakan teknik pengumpulan data berupa wawancara, observasi, dan dokumentasi.

\section{II.PEMBAHASAN}

\section{A. Gambaran Umum Lokasi Penelitian}

Desa Lingga berada pada ketinggian antara $\pm 1.000 \mathrm{~m} \mathrm{~s} / \mathrm{d} 1.300 \mathrm{~m}$ diatas permukaan laut terletak di koordinat $2^{\circ} 50^{\circ} \mathrm{L} . \mathrm{U}, 3^{\circ} 19^{\circ} \mathrm{L} . \mathrm{S}, 97^{\circ} 55^{\circ} \mathrm{BB}-98^{\circ} 38^{\circ} \mathrm{B}$.T, curah hujan rata-rata pertahun adalah $2.000 \mathrm{~mm} \mathrm{~s} / \mathrm{d} 3.000 \mathrm{~mm} /$ tahun, dan suhu temperaturnya adalah $16^{\circ} \mathrm{C} \mathrm{s} / \mathrm{d} 260^{\circ} \mathrm{C}$.

Dari 4 Dusun di desa Lingga kecamatan Simpang Empat Kabupaten Karo, memiliki luas wilayah $1.600 \mathrm{Ha}$ atau $40 \mathrm{Km}^{2}$, dengan pembagian sebagai berikut: Dusun 1 dengan luas $\pm 400 \mathrm{Ha}$, Dusun 2 dengan luas $\pm 300 \mathrm{Ha}$, Dusun 3 dengan luas $\pm 500 \mathrm{Ha}$, dan Dusun 4 dengan luas $\pm 400 \mathrm{Ha}$. Status kepemilikan lahan di Desa Lingga terbagi dalam 3 bagian yaitu: lahan seluas $1.540 \mathrm{Ha}$ adalah milik rakyat, lahan seluas $10 \mathrm{Ha}$ adalah milik desa dan lahan seluas $50 \mathrm{Ha}$ adalah milik pemerintah.

Desa Lingga merupakan bagian dari wilayh kecamatan Simpang Empat kabupaten Karo. Berjarak \pm 4,5 Km dari arah barat Kantor camat Simpang Empat dan berjarak $\pm 12 \mathrm{Km}$ ke arah ibu kota kabupaten, dengan batas-batas sebagai berikut:

1. Sebelah Utara berbatasan dengan Desa Surbakti Kecamatan Simpang Empat

2. Sebelah Selatan berbatasan dengan Desa Kacaribu Kecamatan Kabanjahe

3. Sebelah Barat berbatasan dengan Desa Sirumbia Kecamatan Simpang Empat

4. Sebelah Timur berbatasan dengan Desa Linggajulu Kecamatan Simpang Empat 
Tanah di Desa Lingga Kecamatan Simpang Empat kabupaten Karo merupakan tanah yang subur dan cocok untuk berbagai jenis tanaman. Sehingga lahan di Desa Lingga cocok untuk lahan pertanian pangan seperti: padi, jagung, cabe, tomat, kentang, kol dan tanaman lainnya. Demikian pula tanah kering perbukitan yang sangat cocok dimanfaatkan sebagai area pertanian rakyat seperti kopi, jeruk, cacao, terong, dan lainlain. Sebagian besar lahan yang ada di Desa Lingga dimanfaatkan oleh penduduk untuk kegiatan pertanian dan pemukiman, pada umumnya penduduk di Desa Lingga ini bekerja sebagai petani.

Kehidupan masyarakat Desa Lingga masih sangat kental dengan tradisi-tradisi leluhur seperti: upacara adat-istiadat yang berhubungan dengan siklus hidup manusia (lahir - dewasa/berumah tangga - mati). Upacara perkawinan dan upacara kematian hampir selalu dilakukan oleh masyarakat yang diadakan di Balai Desa (Jambur/los). Namun trradisi sedekah bumi, bersih Desa (seperti Erpangir Kulau, Erkiler, Ndilo Wari Udan, Cawir Bulung, dan lain-lain) tidak lagi dilakukan karena seluruh masyarakat di Desa Lingga sudah memiliki agama yang di akui di Indonesia. Kesenian yang paling disukai oleh warga Desa Lingga dulunya adalah tari-tarian khas adat karo seperti tari Lima Serangkai, tari Ndikkar (pencak silat karo), tari Gundala-gundala, tari Baka, tari Tongkat dan lain-lain. Kegiatan kelompok kesenian tradisional mulai berkurang sedangkan kelompok kesenian modern (keyboard) sudah membudaya pada masyarakat Karo dan meninggalkan kesenian peninggalan nenek moyang masyarakat karo itu sendiri.

Desa Lingga merupakan desa pertanian, maka hasil ekonomi warga dan mata pencaharian warga sebagian besar adalah bertani. Penghasilan rata-rata Desa Lingga tergolong kedalam kategori menengah. Apabila petani di daerah pedesaan sudah memiliki pendapatan yang cukup untuk memenuhi kebutuhan hidup baik untuk diri sendiri maupun untuk keluarganya, maka pada akhirnya perekonomian di pedesaan tersebut akan tumbuh dengan sendirinya. 


\section{B. Latar Belakang Berdirinya Museum Karo Lingga}

\section{Sejarah Museum Karo Lingga}

Museum Karo Lingga ini berdiri di desa Budaya Lingga (disebut juga sebagai lokasi Immemoria Nirwana Graha Aidilla). Aidilla yang berarti suatu keadaan dan pemandangan yang menarik dalam kehidupan desa, baik itu berupa aktivitas kegiatan sehari-hari maupun kegiatan seni tradisi dan budaya ataupun juga didukung ornamenornamen yang ada sebagai penghias desanya.

Sebelum Museum Karo Lingga didirikan, di Desa Lingga ini terdapat banyak peninggalan-peninggalan budaya Karo yang sudah Hampir punah seperti rumah adat Karo yang diperkirakan berumur sekitar 250 tahun, namun masih terdapat beberapa rumah adat Karo yang masih bisa di rawat dan harus dilestarikan.

Setelah peneliti amati ternyata Museum Karo Lingga yang terletak di desa budaya Lingga Kecamatan Simpang Empat Kabupaten Karo, museum ini didirikan dengan bentuk arsitektur tradisional Karo (rumah adat karo). Meskipun bahan bangunannya sudah lebih modern, misalnya atap terbuat dari seng, namun bentuk rumah adat ini terutama pada teras (ture) tetap menunjukkan ciri khas suku Suku Karo.

Sejarah Museum ini diawali dengan kedatangan bapak G.H. Mantik tahun 1979, ketika ia menjabat sebagai Panglima Komando Wilayah Pertahanan II Bukit Barisan. Beliau mengadakan kunjungan kerja di desa Lingga, dalam kunjungannya tersebut beliau terkesan dengan tradisi leluhur karo yang tetap terpelihara. Dalam perjalanan keliling desa Lingga ia tergelincir, ini merupakan hal yang tabu bagi masyarakat Karo. Pada saat tergelincir jiwanya dianggap lengah oleh rasa terkejut dan untuk mengembalikan itu harus diadakan suatu upacara ritual. Atas dasar musyawarah masyarakat dan pengetua adat, didirikanlah sebuah rumah adat di desa yang disebut rumah Tersek.

Karena kesibukan beliau rumah tersebut disebut tidak dimanfaatkan sebagaimana mestinya. Pada tahun 1989 atas prakarsa bapak Acih Ginting seorang tokoh adat di desa tersebut minta persetujuan bapak G.H. Mantik agar rumah adat Tersek tersebut direnovasi untuk dijadikan sebuah Museum yang khusus menyimpan 
benda-benda seni kerajinan dan barang-barang peninggalan suku Karo yang selama ini terdapat didalam rumah adat di desa Lingga. Ini dilakukan untuk menghindari kepunahan, sebab banyak benda-benda kerajinan tradisional Karo hilang bersamaan dengan runtuhnya rumah adat karena dimakan usia. Karena bapak G.H Mantik ini sendiri juga merasa tertarik akan keadaan desa budaya Lingga, maka ia juga merasa perlu didirikan Museum supaya desa budaya lingga terlihat lebih sempurna. Hal inilah yang mendasari Yayasan Museum Karo Lingga di bangun di desa Lingga.

Museum Karo Lingga ini memiliki luas 136 m² (10 m x 10 m dan 3 m x 12 m), didalam bangunan ini terdapat tiga buah kamar tidur (satu di depan dan dua di belakang), sebuah dapur dan dua buah kamar mandi, serta dengan luas halaman $25 \mathrm{~m}$ x $40 \mathrm{~m}=1000 \mathrm{~m}^{2}$. Museum ini didirikan di desa Lingga untuk mempertahankan seni adat kebudayaan kebudayaan suku Karo, yang merupakan benteng budaya suku Karo. Museum Karo Lingga ini mulai dibuka /beroperasi pada tanggal 6 Juni 1986 dengan sekretariat di jalan Kotacane No. 180 Kabanjahe (di dekat terminal simpang empat Kabanjahe).

Meskipun Museum ini terletak di pinggir jalan, karena bentuk dan luasnya yang belum layak dikatakan sebagai museum, namun hal tersebut dapat kita maklumi karena Museum Karo Lingga ini adalah Museum Daerah. Meskipun pihak pengelola yayasan pernah melakukan pameran keliling, pameran khusus, dan sosialisasi ke sekolahsekolah guna memperkenalkan Museum ini namun hal tersebut tidak sesuai dengan apa yang diharapkan karena terkendala di dalam masalah dana. Dengan demikian hendaknya memberikan bantuan dana untuk pengembangan dan mempromosikan Museum Karo Lingga ini agar dapat lebih dikenal lagi oleh masyarakat luas.

Pada awalnya keberadaan Museum Karo Lingga ini hanyalah sebagai pelengkap untuk menambah kekayaan budaya di desa Lingga karena sebelum museum ini dibangun desa Lingga sudah menjadi desa budaya yaitu pada tahun 1977. Berbeda dengan sekarang, keberadaan Museum Karo Lingga ini sudah memberi dampak yang besar bagi desa budaya Lingga karena dengan adanya pembangunan museum ini desa Lingga menjadi ramai dikunjungi oleh pelajar/mahasiswa, wisatawan lokal maupun 
wisatawan mancanegara. Museum ini merupakan salah satu objek wisata di desa Lingga.

G.H. Mantik Manik sebagai pendiri, Acih Ginting sebagai ketua dan merangkap sebagai pendiri, Drs. Tenangta Ginting sebagai sekretaris merangkap sebagai pendiri, Hasan Tarigan BA sebagai bendehara, Edison Milala sebagai pembantu, Bapak Bupati KDH Tingkat II Karo sebagai pelindung, Bapak Kakandepdikbud Kabupaten Karo sebagai penasehat.

\section{Ornamen Yang Terdapat Pada Bangunan Museum Karo Lingga}

Bangunan Museum Karo lingga ini menyerupai bangunan rumah adat tradisional Karo. Ornamen rumah tradisional Karo berhubungan dengan lambanglambang yang terkait dengan adat-istiadat yang diciptakan oleh nenek moyang suku Karo. Berdasarkan penelitian yang telah dilakukan peneliti di Desa Lingga Kecamatan Simpang Empat Kabupaten Karo terdapat ornamen-ornamen yang berada pada bagian Museum Karo Lingga tersebut. Adapun ornamen-ornamen tersebut adalah sebagai berikut: pengeret-ret, tapak raja Sulaiman, embun sikawiten, pakau-pakau, embun merkabun-kabun, mata-mata lembu, bindu matoguh,dan ampik-ampik alas.

\section{Fungsi dan Peranan Museum Karo Lingga}

Museum bukan hanya sebagai tempat penyimpanan benda-benda antik yang dianggap memiliki nilai historis yang tinggi namun juga merupakan wadah dimana masyarakat luas dapat memperoleh informasi tentang benda-benda yang memiliki nilai budaya .

Dalam Vibariani (2007:6) dituliskan bahwa:

Museum berfungsi sebagai berikut:

* Pusat dokumentasi dan penelitian ilmiah.

* Pusat penyaluran ilmu untuk umum.

* Pusat penikmatan karya seni.

* Pusat perkenalan kebudayaan antardaerah dan antarbangsa. 


\footnotetext{
* Objek wisata.

* Media pembinaan pendidikan kesenian dan ilmu pengetahuan.

* Suaka alam dan suaka budaya.

* Cermin sejarah manusia, alam, dan kebudayaan.

* Sarana untuk bertakwa dan bersyukur kepada Yuhan Yang Maha Esa.
}

Museum mengumpulkan dan merawat objek-objek yang bersifat keilmuan, artistik, atau mempunyai riwayat sejarah yang penting dan membuat objek-objek tersebut dapat dinikmati oleh publik melalui pameran yang bisa bersifat permanen (tetap) atau bersifat sementara. Museum-museum yang besar biasanya berlokasi dikota-kota besar (ibukota provinsi) dan dapat dikunjungi oleh warga lokal setempat dan dari kota lainnya, ataupun dari turis berbagai negara.

Dari pemaparan diatas dapat kita ketahui bahwa dalam perkembangan museum ada perubahan-perubahan yang bersifat perluasan dari fungsi museum. Pada awalnya Museum Karo Lingga memang hanya berfungsi sebagai gudang untuk menyimpan warisan-warisan budaya yang memiliki nilai historis dan dianggap patut untuk disimpan. Kemudian fungsi museum ini ditambah dengan fungsi pemeliharaan, pengawetan (Konservasi) dan pameran. Akhirnya fungsi Museum Karo Lingga ini diperluas lagi hingga menjadi fungsi pendidikan dan untuk kepentingan masyarakat secara luas.

Dari hasil penenelitian peneliti Museum Karo Lingga ini memiliki beberapa peranan, yaitu sebagai berikut:

* Sebagai lembaga pewarisan warisan sejarah alam dan budaya

Sebagai sarana pendidikan

Sebagai benteng budaya bangsa

Sebagai tempat mengapreasikan budaya bangsa

Sebagai objek wisata 


\section{Perkembangan Museum Karo Lingga}

Perkembangan permuseuman di Indonesia yang direncanakan sejak pelita I sampai dengan pelita VI dilaksanakan atas dasar keinginan untuk menyelamatkan dan melestarikan warisan budaya dan warisan alam. Disamping itu juga memperkenalkan kepada masyarakat tentang latar belakang budaya provinsi yang bersangkutan dengan berbagai ciri-ciri yang dimiliki meliputi lingkungan alam dan budaya.

Berdasarkan perkembangan Museum, maka dengan ini ada dua hal yang perlu dicatat mengenai sejarah perkembangan Museum, yaitu aspek pertama adalah bahwa museum menjadi tempat umum, karena seirama dengan proses demokratisasi ilmu dan kesenian. Aspek kedua adalah mengenai hubungan pertumbuhan sistem pemerintahan bagi ketatanegaraan, yaitu adanya negara hukum.

Pada tahun 1974 sebelum menjadi museum bangunan museum ini derahkan kepada G.H. Mantik sebagai rumah tendi. Pada tahun 1989 atas prakarsa bapak Acih Ginting seorang tokoh adat di desa tersebut minta persetujuan bapak G.H. Mantik agar rumah adat Tersek tersebut direnovasi untuk dijadikan sebuah Museum yang khusus menyimpan benda-benda seni kerajinan dan barang-barang peninggalan suku Karo yang selama ini terdapat didalam rumah adat di desa Lingga. Pada tahun 1991 Museum Negeri Medan menyumbangkan lemari sebagai tempat menyimpan/menata bendabenda koleksi yang ada di Museum karo Lingga tersebut. Pada tahun 1993 pagar museum yang awalnya berpagarkan kawat direnovasi menjadi pagar tembok.

Berbagai cara dan upaya ditempuh untuk melestarikan suatu bangunan dan lingkungan, melalui pandangan yang bersifat umum suatu bentuk pelestarian bisa dikatakan meniru suatu bentuk bangunan atau menggunakan bentuk bangunan yang baru untuk melengkapi segenap hasrat dan keinginan. Tetapi suatu bentuk pelestarian juga dapat dipandang sebagai wujud dan keinginan untuk tetap mempertahankan sesuatu yang telah ada dan mengembalikan apa yang telah bercerai berai kedalam apa semestinya.

Konservasi atau pelestarian selalu mengungkapkan bahwa suatu bangunan atau lingkungan itu memang layak untuk dipertahankan. Pelestarian itu tidak lekang seiring 
dengan waktu tetapi dapat berubah sesuai dengan keinginan pada saat bangunan itu akan tetap dipertahankan, bisa saja bangunan itu nantinya berubah fungsi dengan tetap mempertahankan bentuk yang telah ada.

Pelestarian tidak terlepas dengan namanya sejarah beserta peninggalannya, karena setiap bangun an pasti memiliki nilai-nilai sejarah yang patut untuk terus dipertahankan. Aktualisasi sejarah sangat dibutuhkan dalam usaha untuk melestarikan suatu bangunan, karena nilai-nilai yang terkandung didalamnya menyangkut budaya yang menyangkut kesemua pihak sehingga dapat sebagai bukti otentik dalam kesejarahan dan lingkungan.

Konservasi yang dilakukan yaitu untuk membersihkan dan mengawetkan tempat benda-benda koleksi seperti poto-poto barang koleksi dan menambahkan keterangan-keterangan pada benda tersebut. Pada tahun 1994 Departemen Pendidikan dan kebudayaan Provinsi Sumatera Utara menyumbangkan dana untuk dilakukan pengecatan bagunan Museum Karo Lingga sekaligus pemasangan sumur bor.

Sapo gedang gedang ini dibangun pada tahun 1995, dan sapo gadang ini berisi peralatan bertani/berladang seperti:

- Tenggala digunakan untuk membuat jalur-jalur dan menutupi tumput yang ada pada batang padi pada waktu berumur 40 hari

- Sisir digunakan untuk meratakan tanah dan memecahkan gumpalan tanah yang belum hancur dan juga membersihkan rumput

- Roka digunakan untuk membuat petak-petak pada ladang atau sawah yang hendak ditanami padi, dan lain sebagainya.

Sejak tahun 1994 koleksi museum ini sudah ikut dipamerkan dalam acara pesta buah dan pesta bunga setiap tahunnya dan terakhir kali dilakukan pada tahun 1997. Pada tahun 1998 Departemen Pendidikan dan Kebudayaan Provinsi Sumatera Utara menyumbangkan stailing sebagai tempat menata patung pengantin. Pada tahun 2009 dinas pariwisata provinsi mengadakan seminar Museum Dihati yang dilaksanakan di depan Museum Karo Lingga, dari kegiatan ini menciptakan duta-duta Musem dan yang 
menjadi utusannya adalah anak-anak sekolah si tanah karo. Museum Karo Lingga ini juga masuk dalam keanggotaan Asosiasi Museum Indonesia sejak tahun 2010 sampai sekarang (kegiatan tersebut dilakukan setiap tiga tahun sekali).

\section{Koleksi Museum Karo Lingga}

Koleksi adalah tulang punggungnya Museum, kalau tidak ada koleksi berarti tidak ada museum. Dengan demikian koleksi (benda-benda warisan sejarah alam dan budaya) merupakan objek pokok dalam pendirian museum dan sebagai bahan untuk penelitian. Benda-benda warisan budaya adalah benda-benda hasil karya manusia dalam memenuhi kebutuhan hidupnya seperti peralatan untuk keperluan rumah tangga, peralatan pertanian serta keperluan religius maupun perlengkapan upacara-upacara tradisi. Warisan alam adalah bahan-bahan tinggalan yang telah mengalami kepunahan, seperti tumbuh-tumbuhan, jenis-jenis kayu, binatang yang telah tinggal namanya.

Museum yang bertugas melestarikan warisan budaya bangsa ini dengan cara mengumpulkan, merawat, meneliti, mengkaji, mengkomunikasikan dan memamerkan untuk kepentingan masyarakat guna untuk studi suatu penelitian/pengkajian pendidikan dan rekreasi dalam rangka ikut mencerdaskan kehidupan bangsa.

Benda-benda koleksi Museum Karo Lingga ini diperoleh dari sekitar desa Lingga,ada yang dibeli dari warga, ada yang disumbangkan, ada yang dititipkan , berbagai cara dilakukan oleh pihak pengelola Museum Karo Lingga untuk memperoleh benda-benda koleksi hingga akhirnya Museum Karo Lingga ini menjadi seperti sekarang ini. Koleksi Museum Karo Lingga ini berjumlah 206 buah yang terdiri dari kain tenun, topeng, mata uang, peralatan dapur peralatan pertanian, peralatan musik, peralatan berburu, peralatan upacara adat, dan peralatan pengobatan.

Koleksi yang terdapat di museum Karo Lingga terdiri atas benda-benda peninggalan budaya masyarakat karo, benda-benda ini di tata sedemikian rupa sehingga terlihat rapi dan menarik perhatian (bila ada benda koleksi yang sama lebih dari satu, hanya satu yang dipamerkan yang lainnya disimpan). Secara umum bendabenda yang terdapat di Museum ini terdiri dari: 
1. Koleksi etnografi merupakan Koleksi benda hasil budaya atau menggambarkan identitas suatu etnis berupa peralatan pencaharian untuk memenuhi kebutuhan hidup, kain dan sebagainya. Berbagai koleksi etnografika yang ada di museum adalah sebagai berikut: tempat sirih dan peralatannya, alat musik tradisional Karo, topeng seni pertunjukan, kudin gelang-gelang dan gumbar, aksara Karo, kain tenun masyarakat Karo, tabu-tabu dan kepuk, kuran, tongkat (ciken), dan perikanan (bubu).

2. Koleksi arkeologika adalah benda koleksi yang merupakan hasil budaya manusia masa lampau yang menjadi objek penelitian arkeolog. Benda-benda tersebut merupakan hasil tinggalan budaya sejak masa lampau hingga masuknya pengaruh budaya barat. Koleksi ini antara lain: patung nenek moyang, patung Dibata, dan pagar jabu.

Patung nenek moyang dan patung dibata (Tuhan) ini terbuat dari batu dan katu yang diukir sedemikian rupa oleh masyarakat Karo. Patung ini dianggap membawa keberuntungan dan mempunyai kekuatan gaib karena telah dirasuki oleh suatu roh yang kuat yang dianggap sebagai Tuhan. Patung ini diperkiran berumur dua ratus tahun lebih.

Dahulu masyarakat Karo percaya bahwa suatu rumah tangga yang tidak dilindungi dengan pagar jabu, maka rumah tersebut akan sering mengalami alhal yang tidak diinginkan misalnya, kemalingan, penyakit, kematian dan lain sebagainya. Oleh sebab itu makanya setiap rumah harus menyimpan pagar jabu sebagai pelindung dan dari hal yang tidak diinginkan.

3. Koleksi numismatika Merupakan koleksi mata uang atau alat tukar mulai masa Indonesia kuno, masa pemerintahan Belanda, Inggris, Jepang, sampai kini. Sebelum bangsa asing masuk, etnis di Sumatera utara termasuk sub etnis Batak Karo belum mengenal uang sebagai alat tukar, yang berlaku hanyalah sistem barter. Tetapi setelah masuknya bangsa asing yaitu Belanda telah beredar bermacam-macam uang misalnya: Rijksdealer, dukat, stiver, gulden, doit, ruver, dan lain-lain. 
Demikian pula halnya dengan penjajahan Jepang telah diterbitkan mata uang kertas yang disebut uang rupiah berbentuk segi empat dan pada sisi muka terdapat tiga baris tulisan pemerintah Nippon. Setelah Indonesia merdeka uang rupiah telah menjadi alat pembayaran yang sah hingga sekarang.

4. Koleksi filologika merupakan benda koleksi yang menjadi objek penelitian filologi berupa naskah kuno yang ditulis dengan tangan yang menguraikan suatu hal atau peristiwa.

Pustaka Lak-lak merupakan tulisan kuno yang ditulis oleh raja-raja atau dukun pada zaman dahulu. Pustaka lak-lak terbuat dari kayu jelutung dan kayu pulai yang dihaluskan. Seperti buku Harmonika, kulit buku ini terbuat dari papan yang diukir dengan arti Tuhan yaitu dari kesuburan sementara itu disisi yang lain diukir dengan 5 bintang yang berarti isi kitab ini adalah bagaimana cara membuat obat, mantra-mantra, dan lain sebagainya, kitab ini berusia \pm 125 tahun.

5. Koleksi keramologika adalah benda koleksi yang dibuat dari tanah liat yang dibakar berupa barang pecah belah, koleksinya aantara lan adalah:

i.Kudin Taneh

Kudin taneh terbuat dari tanah liat yang dibakar. Dahulu masyarakat Karo menggunakan alat ini memasak sayur atau gulai ikan terutama ikan mas.

ii.Pinggan Pasu

Pinggan pasu ini juga termasuk ke dalam koleksi kremalogika karena terbuat dari bahan yang sama. Fungsi dari pinggan pasu ini adalah untuk menghidangkan sajian bagi mempelai ataupun tamu kehormatan dengan nasi, seekor ayam beserta lauk pauknya. 


\section{E. Usaha Pengelola Museum Dalam Melestarikan Koleksi Museum Lingga}

Pengelolaan koleksi Museum Karo Lingga ini adalah serangkaian kegiatan yang menyangkut berbagai aspek kegiatan, dimulai dari pengadaan koleksi, registrasi dan inventarisasi, perawatan, penelitian sampai koleksi tersebut disajikan di ruang pamer atau disimpan pada ruang penyimpanan.

Melakukan registrasi dan inventarisasi koleksi yang merupakan suatu suatu kegiatan pencatatan mengenai keadaan koleksi (keluar-masuknya koleksi) serta pendeskripsian koleksi, baik secara verbal (tertulis) dan pictorial (foto/gambar) yang diuraikan secara singkat dan jelas.

Bentuk dan luas Museum Karo Lingga yang belum layak dikatakan sebagai museum, namun hal tersebut dapat kita maklumi karena Museum Karo Lingga ini adalah Museum Daerah. Pihak pengelola yayasan juga pernah melakukan pameran keliling, pameran khusus, dan sosialisasi ke sekolah-sekolah guna memperkenalkan Museum ini namun hal tersebut tidak sesuai dengan apa yang diharapkan karena terkendala di dalam masalah dana.

\section{PENUTUP}

Berdasarkan hasil penelitian yang telah dilakukan penulis, maka diperoleh kesimpulan bahwa Sejarah Museum ini diawali dengan kedatangan bapak G.H. Mantik tahun 1979, ketika ia menjabat sebagai Panglima Komando Wilayah Pertahanan II Bukit Barisan. Beliau mengadakan kunjungan kerja di desa Lingga, dalam kunjungannya tersebut beliau terkesan dengan tradisi leluhur karo yang tetap terpelihara yang tetap terpelihara. Museum Karo Lingga dibangun pada tahun 1977 yang diprakarsai oleh G.H. Mantik.

Semua koleksi yang ada di museum ini merupakan peninggalan yang berhubungan dengan kehidupan masyarakat Karo, sebagai bentuk melestarikan budaya Karo agar dapat mengingatkan masyarakat tentang kebudayaan asli suku Karo sebagai jejak peninggalan nenek moyang mereka. 
Museum Karo Lingga ini bukan hanya sekedar tempat wisata, namun museum juga dapat dijadikan tempat belajar dan mendapatkan ilmu pengetahuan atau untuk tempat pameran dari isi museum tersebut. Di Desa Budaya Lingga ini museum Karo Lingga kurang di lestarikan dan diminati oleh masyarakat atau pemerintah, karena kurangnya ketertarikan masyarakat terhadap museum, serta fasilitas yang kurang mendukung

Meskipun Museum ini terletak di pinggir jalan, karena bentuk dan luasnya yang belum layak dikatakan sebagai museum, namun hal tersebut dapat kita maklumi karena Museum Karo Lingga ini adalah Museum Daerah. Meskipun pihak pengelola yayasan pernah melakukan pameran keliling, pameran khusus, dan sosialisasi ke sekolahsekolah guna memperkenalkan Museum ini namun hal tersebut tidak sesuai dengan apa yang diharapkan karena terkendala di dalam masalah dana. Dengan demikian hendaknya memberikan bantuan dana untuk pengembangan dan mempromosikan Museum Karo Lingga ini agar dapat lebih dikenal lagi oleh masyarakat luas.

Aktivitas masyarakat desa Lingga yang berada di sekitar Museum Karo Lingga pada umumnya adalah bertani, tetapi jika ada acara-acara khusus di Museum Karo Lingga ini juga diadakan berbagai jenis pameran seperti Ndikkar (silat karo), dan tari tradisional budaya Karo. 


\section{DAFTAR REFERENSI}

Album Budaya. (2012). Direktori Museum Indonesia. Jakarta: Kemendikbud.

Holmes, dkk . (2013). Konservasi Desa Lingga. Sumatera Utara: Universitas Katolik Santo Thomas.

Bukit, Doni. (2016). Kecamatan Simpang Empat Dalam Angka. Berastagi: Badan Pusat Statistik Kabupaten Karo.

Daliman. (2012). Metode Penelitian Sejarah. Yogyakarta: Ombak.

Hardjana. (2002). Museum-Museum Pemerintahan DKI Jakarta. Jakarta: CV Widya Lika Utama.

Kriwanto, Joosten. (2014). Tanah karo selayang Pandang. Medan: Bina Media Printis. Kuntowijoyo. (2005). Pengantar Ilmu Sejarah. Jakarta: Benteng Pustaka.

Prinst, Darwan. (2011). Adat Karo. Medan: Bina Media Printis.

Sarjani. (2009). Lentera Kehidupan Orang Karo dalam Berbudaya. Medan: BNB Press Sarjani. (2014). Sekilas Sejarah Pemerintahan Tanah Karo Simalem. Medan: Si BNB Press.

Sjamsuddin, Helius. (2007). Metodologi Sejarah. Jakarta: Ombak.

Sugiyono. (2010). Metode Penelitian Kuantitatif Kualitatif. Bandung: Alfabeta.

Sumadio, Bambang. (1997). Bunga Rampai Permuseuman. Jakarta: Departemen Pendidikan dan Kebudayaan.

Suroso, Urip. (1994). Pedoman Tata Pameran di Museum. Jakarta: Departemen Pendidikan dan Kebudayaan.

Vibariani, Miyarso. (2007). Sejarah Mengenal Museum. Bandung: Widya Duta Grafika. 